Polgári Szemle, 16. évf. 4-6. szám, 2020, 243-257., DOI: 10.24307/psz.2020.1017

\author{
Tózsa István
}

\title{
Az alvilág földrajza
}

\section{Geography of the Underworld}

\section{Összefoglalás}

A görög-római mítoszok világa az európai kultúra egyik fő tartóoszlopa a zsidó-keresztény vallás és a kelta-germán hagyományok oszlopai mellett. Ez az írás a görög hitvilág egyik nagy „földrajzi” egységét, az alvilágot mutatja be a festô- és szobrászmúvészet, valamint az európai civilizáció legósibb legendáinak segítségével. A görög-római mitológia alvilágképe a mítoszokban sokszor jelenik meg; ismerete az európai múveltség része. Gondoljunk Héraklész, Orpheusz, Aeneas és Odüsszeusz alvilági látogatásaira, Perszephoné házasságára, Sziszifusz, Tantalosz vagy a Danaidák büntetésére. Kharónra, a révészre, az érchangú Kerberoszra, a Felejtés vizére, a Léthére. Az alvilág istene és uralkodója, Hadész saját nevét kölcsönözte a görög túlvilágnak, amely mélyen Európa alatt található, az Atlanti-óceántól a Fekete-tengerig, illetve a Kaukázusig. Amikor a Föld és az Ég (Gaia és Uranosz) egyesülését követôen, az Idô (Kronosz, latinul Saturnus) által vezetett titánok uralkodása után az istenek vették át a hatalmat a világon, a három fiú felosztotta azt egymás között. A legfiatalabb, Zeusz (Jupiter) uralkodik a földön és az égen; a középsố fiú, Poszeidón (Neptunusz) a tengereken; míg a legidôsebb, Hadész (Pluto) lett az alvilág ura.

Kulcsszavak: görög-római mitológia, európai kultúra, Hadész a múvészetekben

\section{Summary}

The world of Greco-Roman myths is one of the main pillars of European culture alongside Judeo-Christian religions and Celtic-Germanic traditions. This writing presents one of the great "geographical" units of the Greek myths, the underworld, with the help of paintings, sculptures and the most ancient legends of the European civili-

Prof. DR. Tózsa István, egyetemi tanár, Nemzeti Közszolgálati Egyetem (Tozsa.Istvan@uni-nke.hu). 
zation. The image of the underworld in Greco-Roman mythology appears many times in myths; its knowledge is part of the European literacy. Remember the visits of Heracles, Orpheus, Aeneas, and Odysseus to the underworld, the marriage of Persephone, the punishment of Sisyphus, Tantalus, or the Danaids. Think of the stern Charon, the gloomy ferryman, and the metallic toned Cerberos, or the water of oblivion, the River Lethe. The god and ruler of the underworld, Hades, lent his name to the Greek land of afterlife; thought to be located deep below Europe and extending from the Atlantic Ocean to the Black Sea and the Caucasus Mountains. When, after the unification of Earth and Heaven (Gaia and Uranus), the gods took over the world after the reign of the Titans led by Time (Kronos, or Saturn), three great godly brothers divided it among themselves. The youngest one, Zeus (Jupiter) reigns over the Earth and the skies; the middle son, Poseidon (Neptune) over the seas; while the eldest one, Hades (Pluto) became lord of the underworld.

Keywords: Greco-Roman mythology, European culture, Hades in the arts

\section{AHOL A MADÁR SEM JÁR}

„Kháron ladikja nem akkor indul velünk / midôn lezárul és befagy a szem. / Zord átkelók soká nyitott szemmel megyünk / a végzetes vizen” - írja Illyés Gyula a Kháron ladikján címú versében. Arra az európai kultúrában elterjedt ókori elképzelésre utal, hogy halálunk után a lelkünket a lélekkísérő Hermész isten kalauzolja el a távoli nyugatra, jelesül az Atlanti-óceán partjára, ahol alászállva, egy folyón kell átkelnünk, egy zord révész - Kharón - ladikján, feltéve, ha tudunk neki fizetni a pénzérmével, amelyet hozzátartozóink a halálunk után a szemünkre helyeztek. Ez a folyó, amely Európa atlanti partvidéke alatt található a mélyben, jéghideg, mozdulatlan vizú, s a neve Styx, ô a Gyúlölet istennôjének megszemélyesítője. Ez határolja az Európa alatt elterülô alvilágot, melynek neve - az uralkodójáról, Zeusz idôsebb testvéréról elnevezve - Hadész.

Az alvilágot ezen a nyugati határfolyón, a Styxen kívül még öt másik folyó osztja részekre. A halottak lelkei, miután Kharón átszállítja óket a Styxen, áttetszó szellemalak formájában lebegnek a hatalmas, hamuszürke aszphodéloszi mezókön, ahol a csendet csak az érchangú, pokoli ôrkutya, a Kerberosz csaholása töri meg. Az aszphodélosz egy liliomfajta, melyet az ókorban sírokra ültettek; ez a kis virág a Könny istennőjének megszemélyesítője. Az alvilági Aszphodélosz Nyugat- és Közép-Európa alatt terül el; északról - nagyjából az Északi- és a Balti-tenger alatt - az Akherón nevú folyó határolja, mely az örömtelenség, vagyis a Bánat istenét személyesíti meg. Az alvilági folyók istenei, mint a felvilági folyókéi is, mindannyian a hatalmas Ókeanosz titán, az Atlanti-óceán és Thetisz titanisz, a Földközi-tenger gyermekei. Az Aszphodéloszt délról, tehát nagyjából Dél-Európa alatt a Kókütosz, vagyis a Jajveszékelés folyója határolja. Kelet felől, Kelet-Európa alatt pedig a híres Léthe vize határolja a hamumezóket: ez 
a Felejtés vize, ide járnak inni a holt lelkek. Minél többet isznak a Léthéból, annál inkább elfelejtik óket a felvilági rokonaik, leszármazottjaik. Csak azok a holt lelkek nem szomjaznak meg, akiket gyakran emlékezetükbe idéznek az élók, akiket gyakran emlegetnek. Az ókorban még áldoztak a halottnak, az áldozati állatok földre csurgatott vérét a föld beszívta, s lent a Hadészban a holt lélek, ha ezt megitta, újra, rövid idôre éloonek érezte magát.

A Léthe vizén túl - tehát Kelet-Európa és a Kaukázus vidéke alatt - egy rettenetes ércküszöb mögött irdatlan, örök sötétség uralkodik. Ennek a vidéknek a névadója és uralkodója Erebosz, az örök Sötétség istensége, aki a Káoszból kiemelkedó négy elsó létezô egyike, s Gaia Földanya testvére. Itt lakik Nyx, Erebosz másik testvére, az Éjszaka istennője, aki minden napszálltakor felszáll a világra, és ráborítja éjszínú leplét. Itt áll Hadész palotája is, benne az alvilág ura, Hadész, latinul Pluto, és felesége, a Pusztulást hozó Perszephoné istennó. Itt élnek az alvilági istenek. Köztük a legismertebb Hekaté, a Boszorkányság és a Búbájosság istennője. Továbbá itt élnek az éjszaka gyermekei. Ốk Nyx és Erebosz utódai. Elsôsorban Thanatosz, a Halál és testvére, Hüpnosz, az Álom, valamint Erisz, a Viszály istennôje. Rajtuk kívül még számos istenség tanyázik itt, akik Nyx utódai, és éjszaka, vele szállnak fel az emberek közé. Ốk a pénz, a betegség, a gyilkosság, az öregség, az irigység, a bosszú, a gúnyolódás, a csalás, a butaság, a szeretkezés, a kéjvágy, a nyomor, a düh, a hiba és az ôrület istenei, és a gyermekeket elragadó vámpírok.

A Dél-Európa alatt húzódó, jajveszékelô Kókütosz folyón túl sötét, izzó, sziklás hegyormok látszanak a Földközi-tenger alatt. Ez maga a Pokol, melynek neve és istensége Tartarosz, ó is egyike a négy elsô létezônek. Itt bûnhôdnek a búnösök. A Tartaroszt délrôl, Észak-Afrika partvidéke alatt a Phlegethón, vagyis a Lángolás nevú tûzfolyó határolja. Végül az Akherón folyó túlsó partján, észak felé, tehát Észak-Európa és Skandinávia alatt található az alvilági Mennyország, ahová a jó emberek és a hírességek szellemárnya, lelke kerül. Szürke, vigasztalan égbolt alatt végeláthatatlan almáskertek vannak itt; ez az Elízium, a boldogok szigete, amit Kronosz (latinul Saturnus), az Idó titánja - Zeusz apja - kormányoz. Sziget, mert északról, nagyjából az Északi-sarkvidék alatt ismét egy folyó határolja: az Aornis - jelentése: a madár nélküli. Vagyis ott, ahol a madár sem jár, az a világ vége. Az alvilágé is.

\section{HADÉSZ}

A legôsibb európai teremtéstörténet a Theogónia, amely Krisztus elôtt a nyolcadik században Hésziodosz görög költô és történetíró nevéhez kötődik. A Theogónia, vagyis az istenek származástana szerint a mindent megelôzô, kavargó ôsanyagból, a Khaoszból emelkedett ki a négy elsố létezô entitás. Két hímnemú: az örök Sötétség (Erebosz) és az alvilág mélye, a Pokol (Tartarosz); valamint két nônemú: az Éjszaka istennője, Nyx, aki minden éjjel ráborítja sötét fátylát az egész világra, és a Földanya istennô, Gaia, „aki az ifjakat felneveli”. Gaia, a Földanya maga teremtette meg a saját párját, a föld elsố urát, az ég királyát, Uranoszt. A Föld és az Ég egyesüléséből születtek a „nagyratörő” titánok és nối párjaik, a titaniszok. A titánok vezére, az „álnok” Idő (Kronosz 
vagy latinul Saturnus) megölte atyjukat, Uranoszt, s ó, az Idô vette át a hatalmat a világ felett. Feleségül vette Rheát, az időnek leginkább ellenálló tölgyfa titaniszát, s halhatatlan istengyermekeiket lenyelte, nehogy egyszer azok fosszák meg hatalmától, ahogy ó tette a saját apjával. Hat istengyermekük közül három leány volt. A legidôsebb Hesztia (Veszta), az otthon és a házi túzhely ôrzője. A középsô, Démétér (Ceres) a gabona és a termékenység istennôje. A legfiatalabb, Héra (Juno) a család istennôje. A három fiú közül Hadészt és Poszeidónt szintén elnyelte az Idô titánja. De Rhea, a tölgyfa istennője megelégelte Kronosz eljárását, s a hatodik gyermekét titokban szülte meg Árkádiában, a Lyakón-hegy barlangjában. Hogy fájdalmát csendben kibírja, fogai közé egy tölgyfaágat szorított, s ujjait a szülési fájdalom hatására mélyen belevájta a barlang talajába. Mivel Rhea hatalmas istennố volt, az így kivájt barlangi földból azonnal kis istenségek alakultak ki: az Ujjak (Daktüloszok), a Vas, az Acél, a Kalapács, az Ülló és a Kés - ôk fémjelzik a mitológiában a Zeusz megszületésével kezdődô vaskorszakot az európai ôstörténelemben. Rhea, a Tölgyfa istennố a megszületett legfiatalabb fiúgyermek, Zeusz helyett egy követ tett a pólyába, azt adta át Kronosz titánnak; míg a gyermeket Kréta szigetén, a Dikté-hegy barlangjában rejtette el. A gyereket egy Amalthea nevú kecske nimfára - akinek a szarva lett később a bőségszaru, a Szerencse istennôjének, Tükhének (Fortunának) a jelképe - és két fegyveres nimfára, a Kurészek órizetére bízta, akik ércpajzsaikat összeverték, ha a csecsemő Zeusz sírt, nehogy az apja meghallja a gyermeksírást. Kronosz rájött, hogy rászedték, és égre-földre kereste Zeuszt, de sem égen, sem földön nem találta. Azért, mert Rhea a barlang elôtt egy tölgyfa ágára akasztotta Zeusz bölcsôjét, s így a gyermek sem a földön, sem az égen nem volt. Innen az Európa-szerte elterjedt „égen-földön keresi” szólás eredete. Zeusz felnôve és megerôsödve legyốzte az Idôt, és kiszabadította testvéreit - ezzel halhatatlanná váltak. Zeusz, a gyôztes legfiatalabb fiú - mint a mesékben - a villám isteneként uralkodott a földön és az égen. A középsô, Poszeidón kapta tôle a tengereket, míg Hadésznak, a legidôsebbnek az alvilág jutott.

Ez az írás a Hadész által uralt és kevesek által ismert mitológiai alvilág földrajzát, tájait és lakóit mutatja be. Az ókori görög mitológia a bronzkortól a vaskoron át évezredek óta máig fennmaradt elsô valódi és kizárólag európai vallás tükörképe. Ismerete az európai identitás kognitív része. A görög mitológia történetei, alakjai, az olimposzi istenek családja még hellyel-közzel ma is ismert, bár mióta az alap- és középfokú oktatásból a második világháború utáni hét évtizedben teljesen kiszorult a latin nyelv oktatása Horatius, Vergilius, Ovidius múvei alapján, az európaiak görög mitológiára vonatkozó aktív tudása is megcsappant. Az európai, klasszikus múalkotások, festmények, szobrok zömét is hovatovább már csak mobiltelefonos segítséggel tudják értelmezni. Ennek a tanulmánynak a témája pedig éppen a görög mitológia talán legkevésbé ismert régiója, az alvilág, a Hadész, amelyet Európa alatt képzelt el az ôsi görög civilizáció.

Az alvilág négy nagy tartományból áll, melyet tehát hat folyam választ el egymástól. Nyugaton, az Atlanti-óceán partvonalánál, éppen a mai Portugália alatt folyik, vagy inkább mozdulatlanul áll, a jéghideg és mérgezô vizú Styx, a „Gyúlölet”, az alvilág legnagyobb határfolyója. Az Északi-sark alatt folyik az alvilág egyik szélsô, északi tar- 


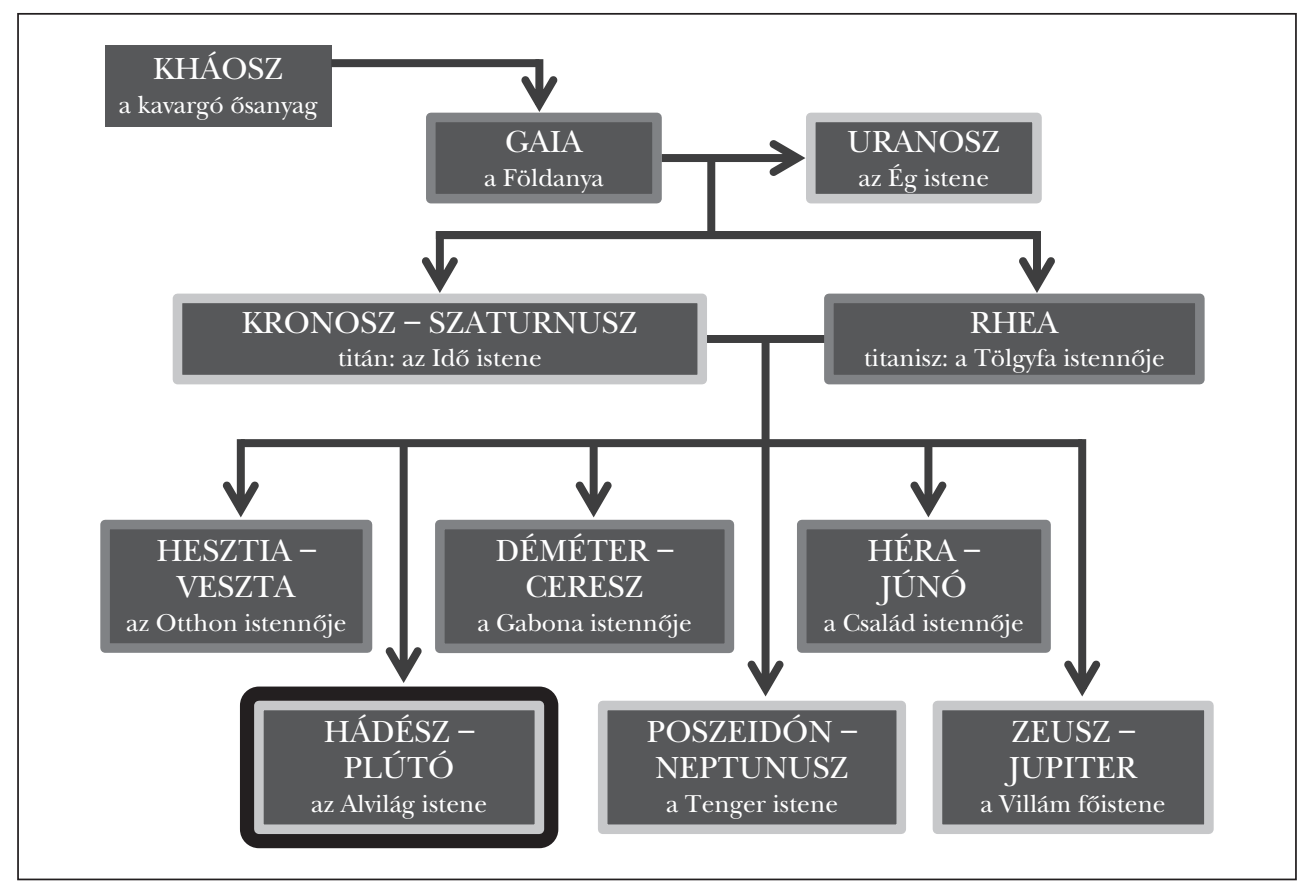

Forrás: Saját szerkesztés

tományát északról határoló Aornis, a „madár nélküli” - innen az európai népmesei szólás: Hol jársz itt, ahol a madár sem jár? Tudniillik: a világ végén. Az Akherón az „öröm nélküli”, vagyis a Szomorúság folyója az alvilág legnagyobb tartományát, a holt lelkek többségének lakhelyét határolja észak felól. A holtak lakhelyét az alvilági istenek lakhelyétôl és Hadész palotájától a Léthe, vagyis a „Felejtés” vize határolja, ahová a holtak inni járnak. Minél többet isznak a Léthe vizéból, annál kevesebbet gondolnak rájuk élô rokonaik és ismerôseik. Az alvilág mélyének, a Pokolnak a két határfolyója a Kókütosz, a „Jajgatás” és a Phlegethón, a „Lángolás”.

Az alvilág nagy tartományai közül egyik a „mennyország,” az Elízium, a Boldogok szigete az Aornis és az Akherón vize között. Ezt a régiót Európa alatt, a ködös északon, azaz - utólag mondhatjuk: stílszerúen - a mai Skandinávia és Észak-Európa alatt képzelték el a görögök. Ez a táj földrajzi szempontból meglehetôsen vigasztalan: ködös, végeláthatatlan almáskertek alkotják, melyet szürke égboltként fed le az alvilági boltozat. Ide a jó emberek mellett a királyok és uralkodók szellemalakot öltô lelkei kerülnek. Az Elízium egyik kijárata a Fekete-tenger mai romániai partvidéke mentén található kopár sziget, a Kígyó-sziget, amelyet a rómaiak számúzetési helyként, börtönszigetként használtak. Itt írta például János evangélista számúzetésében a Jelenések könyvêt. A kis szigeten sokáig volt szentélye Akhilleusznak és Szép Helénának, akiket elíziumi álompárként tartottak számon az ókorban. Akhilleusz viszont azt mondotta a vele pár szót váltó Odüsszeusznak, amikor az bolyongásai során az Akherón kapujánál 


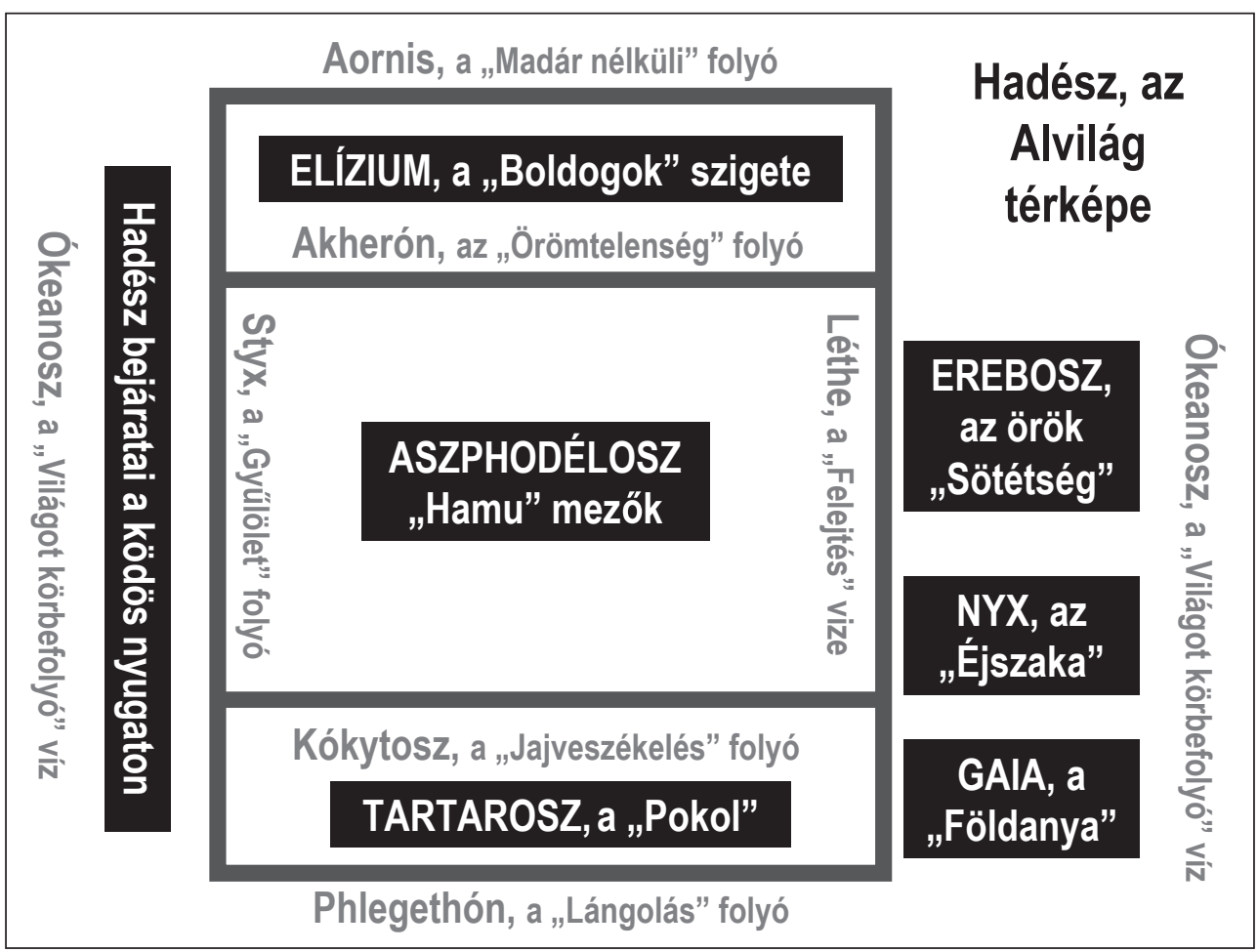

Forrás: Saját szerkesztés

(torkolatánál) találkozott vele, hogy inkább lenne a legnyomorultabb, de élố szántó-vetố ember, mint király a holtak birodalmában.

A Styx, az Akherón, a Léthe és a Kókütosz vizei által határolt hatalmas régió a holt lelkek szellemalakjainak lakhelye, az Aszphodélosz. Ez az alvilági régió Nyugat-, Dél-és Közép-Európa hatalmas föld alatti vetülete. A tájkép lehangoló: egy homoksivataghoz hasonló, végtelen hamumezô, kisebb-nagyobb dombokkal, melyre fekete égboltozatként borul a föld. Az aszphodéloszi hamumezókön kóborolnak vagy denevérekhez hasonlóan repdesnek céltalanul a holt lelkek - éló formájukhoz hasonlatos szellemalakzatként milliószámra, a fecskék csiviteléséhez hasonló hangokat kiadva. A fecske a Halál (Thanatosz) és az Álom (Hüpnosz) testvérpár szent madara, a testból a halálkor és az alváskor egyaránt elszálló lélekkel azonosították. A holtak szelleme csoportosan jár inni az Aszphodéloszt az örök sötétség honától elválasztó ércküszöb mentén található Léthe folyó vizéhez. Egyetlen örömük, ha a felsố világban vér folyik a földre - jelesül, ha élố rokonaik véráldozatot mutatnak be a tiszteletükre vagy emlékükre, s az áldozat (kezdetben ember, késóbb állat) vérét a földre csorgatják. Ilyenkor, ha ihatnak a föld által beszívott, nekik szánt vérból, áttetszố szellemalakjuk átszínesedik, és egy ideig ismét embernek érezhetik magukat. Ahogy ezek az áldozatok elmaradnak, vagyis egykori rokonaik, barátaik mindinkább elfeledik a holtakat, már csak a Léthe 
vizével tudják csillapítani a szomjukat, ezért egyre áttetszőbbé válnak, mígnem végleg szétoszlanak, azaz elfelejtődnek. A Léthe nemcsak a Felejtés, de a Megbocsátás vize is, ezért minél többet iszik egy holt lélek a vizéból, annál inkább csak a jó dolgokra fognak emlékezni az élô hozzátartozói. Innen ered az európai mondás: „Halottakról vagy jót, vagy semmit".

A civilizáció hajnalán és az ókorban, amikor egy ember meghalt, a szájába vagy a szemére egy rézpénzt (obulus) helyeztek. Ez a Révész díja volt, mely nélkül a halott lelke nem juthat le az alvilágba, és visszajár kísérteni. Hogy ezt elkerüljék, a gyászolók korommal kenték be az arcukat, megszaggatták ruhájukat, karmolták, összevérezték az arcukat, hogy a megholt szelleme ne ismerje fel óket. Innen származik az európai gyászruha fekete színe, bár magának a halálnak a színe a vörös volt, asszociálva a vérre, hiszen a történelmi idókben gyakori volt az erôszakos halál. A holt lelkeket az utasok istene, Hermész - az egyik hatalmas olimposzi isten - „lélekkíséróként” kalauzolja, vezeti nyugatra, ahol a ködbe veszô, végtelen óceán határolja Európát. Itt - tehát a mai Portugália alatt - található az alvilági fóbejárat; egy ködös, fekete nyárfaligetben várakozik a holtak szelleme a jéghideg, mérgezô vizú, gyúlöletes Styx folyó partján.

Magyarországon is van egy Styx, mégpedig a hatalmas, aggteleki Baradla-barlangnak ma Szlovákiába átnyúló, Domica nevú ágán folyik végig. Az aggteleki barlangrészre megérkezve, a Hangverseny-teremben torkollik az Akherónba a Baradla másik alvilági nevú folyójába. Innen Akherón néven folyik végig a Baradla főágán Jósvafô felé, s a hatalmas Óriások terme elôtt egy víznyelooben eltûnik. A máig felfedezetlen, aktív, vízzel kitöltött Alsó-barlangban folyik néhány kilométert, s Jósvafőn a Tengerszem mellett, immár Jósva-patak néven jut napvilágra - bóvizú forráspatakként. A görög mitológia nem eléggé rendszerezett ismerete miatt a két magyarországi föld alatti patak, a Styx és Akherón névadása fordítva történt; nem a Styx folyik az Akherónba, hanem fordítva, ezért a Jósva-patak föld alatti részét Styxnek s nem Akherónnak kellett volna nevezni.

„Hadész kapuja”, melyet Jézus is meglátogatott, egykor egy megmérhetetlen mélységú tó volt a barlangban, gyakorlatilag a Jordán forrása, amely ma már földrengés miatt nem a barlangból folyik ki Izrael állam északi részén, Caesarea Philippinél. Hadész „hivatalos” bejáratának romjai ma: az ókori Hierapoliszban (ma a törökországi Pamukkalében) épített templom, amely egy - ma is - vulkáni utómúködés miatt mérges gázokat kibocsátó barlangra épült. Ezeken kívül az alvilágnak voltak más, mérgezô, bódító gázzal töltött hasadék- vagy barlangbejáratai is, amelyek még a középkorban is fennmaradtak. Ilyen például az írországi Lough Derg tó szigetén található, Szent Patrik purgatóriumának is nevezett barlang, ahová 1408-ban a magyarországi „Pokoljáró” Tar Lórinc is elzarándokolt, a krónika feljegyzése szerint.

Visszatérve a mitológiabeli Styxre, a holtak szellemei a náluk lévố rézpénzzel kifizetik a zord alvilági révészt, Khárónt, aki átviszi óket - már akit tisztességesen, viteldíjjal ellátva indítottak útnak a hozzátartozói - az aszphodéloszi hamumezókre. Innen már nincs visszaút. Egy rettenetes, érchangú, háromfejú, pokoli kutya ôrzi a Styx partját, a Kerberosz. ${ }^{1}$ Khárón - aki Nyx, az Éjszaka és Erebosz, a Sötétség fia - igen keveset beszél: a holt lelkek kérdésére, hogy hová fognak kerülni, mi az úti cél, csak ennyit 
felel: „az út hosszú, és a célnak nincs neve”. A sötét túlparton a holt lelkek egy alvilági bíróság elé kerülnek. Minósz a fóbíró, Zeusz egyik halandó fia a föníciai Európé királylánytól, a krétai, minószi birodalom megalapítója. ${ }^{2}$ Zeusz másik két halandó fia közül Aiakosz az európai, Rhadamanthüsz pedig a kis-ázsiai holtak felett bíráskodik. Ha előkeló származású, királyi, uralkodói család tagja a megholt, akkor mindenképpen a viszonylag kedvezőbb adottságú Elíziumba jut, ahogy akkor is, ha nagyon jó ember volt az elhunyt. Ha viszont rossz volt, a Pokolba, a Tartaroszba került; ha pedig sem nagyon jó, sem nagyon gonosz nem volt - ahogy a legtöbb ember -, az Aszphodéloszba került a szellem alakja.

\section{TARTAROSZI TÁJKÉPEK}

Az Aszphodéloszt délrôl a Jajveszékelés folyója, a Kókütosz határolja Dél-Európa alatt. Nagyjából a Földközi-tenger alatt található maga a Pokol, a Tartarosz - késóbb erról nevezték el a könyörtelen mongol hódítókat pokolfajzatnak, vagyis tartaroknak, magyarul tatároknak. A Tartarosz az alvilág legmélyebb része, egy sziklás, szakadékos, félelmetes sötét hegylánchoz hasonlít. Fekete és forró szikláit délrôl Észak-Afrika alatt a lángoló túzfolyó, a Phlegethón festi meg vörös fénnyel. A későbbi európai keresztények pokolképét a Tartarosz ihlette: a lángolást, a jajveszékelést, a búnös lelkek égését, örök szenvedését. A hanghatásokat tekintve, míg az Elíziumban teljes a csend, az Aszphodéloszon csak a holtak halk csivitelése hallatszik, addig a Tartaroszban a Kókütosz folyó partján kínzott szellemek szakadatlan üvöltése, jajgatása és a déli határfolyó vörös lángolása kelt baljós, félelmetes hangulatot.

Egyes mitológiai alakok büntetése közismert. A Tartaroszban vannak leláncolva az istenekre támadó titánok - Ókeanosz, az Atlanti-óceánt megszemélyesítô titán kivételével. Gaia, a Földanya kétszer is megelégelte unokája, Zeusz autoriter hatalomgyakorlását, s egyszer a gigászokat (a félig kígyó, félig ember alakú óriásokat, a „föld szülötteit”) szabadította az istenekre; egy másik alkalommal pedig magától Tartarosztól született fiát, egy vulkánszerú, tûzokádó óriást küldött Zeusz és az olimposzi istenek ellen. Ez utóbbi a Typhón, akinek a nevéból a tájfun szó keletkezett, s akire Zeusz végül rádobta Szicília szigetét. Most Typhón a Tartarosz központjában van, a földhöz szegezve, s felette füstöl az Etna túzhányó. A gigászok szintén a Tartaroszba vannak bebörtönözve. A legismertebb büntetések a hiábavaló munkát jelenítik meg; a 49 férjgyilkos, líbiai Danaida herceglány büntetése - amiért a nászéjszakán megölték az egyiptomi uralkodó 49 fiát -, hogy egy lyukas hordóba kell vizet hordaniuk, amíg az meg nem telik. Sziszifusz, amiért rászedte Zeuszt, megtévesztette Thanatoszt, a Halált, majd becsapta magát Hadészt is, olyan „sziszifuszi munkára” ítéltetett, hogy egy követ kell felgörgetnie egy hegyoldalon, de az minduntalan visszagördül a völgybe, ezért mindig újra kell kezdenie. A saját gyerekét az istenek lakomáján feltálaló Tantalosz ${ }^{3}$ büntetése az örök szomjúság és éhség, miközben vízben áll, feje felett gyümölcsös ág lóg, de akár fel-, akár lehajol, az inni- és ennivaló visszahúzódik elôle; ezt nevezzük „tantaloszi kínok kiállásának”. Olyan nagy erejú hôsök is találhatók itt, akik elbizakodottságukban az istenekhez mérték magukat. Ilyen Ixión, aki egy tüzes kerékhez 
láncoltan forog. A bûne, hogy Hérára támadt, akit az utolsó pillanatban Zeusz kicserélt egy Hérát formázó felhőre, azaz Nephelére, a felhôistennőre, s így fogant meg Kentaurosz, az elsố kentaur, a félig ember, félig lótestú nép, akik a felhô gyermekeinek tartották magukat. A hatalmas erejú Aóleusz testvérek a Pélión-hegyról égó szálfákat dobáltak az Olimposz-hegyre, az istenek lakhelyére. Elbizakodottságuk oka az volt, hogy egy jóslat szerint sem más ember, sem isten nem ölheti meg óket. Ezért megesküdtek a Styx vizére, hogy Zeusz egyik lányát, a szúz Artemiszt, a vadászat istennôjét magukévá teszik az Olimposzon. Végül maga Artemisz ugrott közéjük fehér szarvas képében. A fivérek egyszerre nyilaztak a gyönyörú vadra, ám a célt elhibázva egymást találták el, és haltak meg, így a jóslat érvényét vesztette - hiszen egymást megölhették. A Styx partján ülnek a Tartaroszban, egy oszlophoz láncolva, hogy örökké emlékezzenek be nem tartott esküjükre.

\section{EREBOSZI TÁJKÉPEK}

Az alvilág legsötétebb régiója Erebosz, melyet az egyik elsô létezőről neveztek el, s ez az ó (a Sötétség), valamint Nyx, az Éjszaka istennőjének a lakhelye is. Az Erebosz alvilági vetületét az ókori görögök szerint a hatalmas kelet-európai síkság és a Kaukázus alatt kell elképzelni. Ebben az alvilági tartományban könnyú a tájképet lefesteni: teljes és mérhetetlen sötétség, csend. Ezt bárki könnyen megtapasztalhatja egy kalandtúrán az Aggteleki-karszt nagy barlangjainak egyikében, amikor az egész csoport lekapcsolja a lámpákat, és mindenki csendben marad. Ha kevesen vannak, vagy csak egyedül, olyan tökéletes a csend a nagy barlangok mélyén, hogy elôbb-utóbb meghallja a saját szíve dobbanását is. Az Aszphodélosztól a Léthe vize és egy vasfal, az Ércküszöb választja el Ereboszt. Itt emelkedik az alvilág uralkodójának, Hadésznak az éjszínú palotája is, amely a teljes sötétség miatt láthatatlan - ahogy maga Hadész is az. Itt élnek - de csak nappal - Nyx, az Éjszaka gyermekei. Éjjel a felsố világra mennek. A legismertebb testvérek a Halál és az Alvás, valamint az Álomkép (Phantaszosz, innen a fantázia szavunk). A Halál és az Alvás ókori társításának ténye, hogy ôk ketten testvérek. Az Éjszaka gyermekei nagyrészt ártalmas, nemkívánatos istenségek: az Öregség (Gerosz, innen a gerontológia, az öregséggel foglalkozó tudományterület elnevezése), a viperával ábrázolt Irigység (Battus), a vörös ajkú Gyilkosság (Kér), a Szegénység (Pauritas), a Nyomor (Mizéria), a Düh (Mánia), a Vétek és a Hiba (Error), valamint a Rosszakarat (Malevolantia). Az éjszakai, szamárlábú gyermekrabló kísértet és démon (Empusza és Lamia), a Csalás (Apáté), a Kivégzés és a Bosszúállás (Nemesis), a Butaság (Momos), a Kapzsiság (Mammon). Végül a trójai háborút a „legszebb istennônek” szánt aranyalmával végsố soron kirobbantó Viszály (Erisz) és a Szeretkezés (Philotész) - így megkülönböztetve a szexet a Szépség istennôjétôl (Aphroditétól, ill. Vénusztól) és annak fiától, a Szerelem istenétôl (Erósztól, illetve Ámortól), akik viszont nem az Éjszaka gyermekei.

Érdekes módon Zeusznak Erisztôl, a Viszály istennőjétôl is született egy lánya, Áté, a Hízelgés és Megrontás istennôje, aki olyan szépen tudott beszélni, hogy a hiú Zeusz az Olimposzon tartotta maga mellett. Egyszer azonban, amikor a Héraklész születése körüli eseményekbe a féltékeny Héra - Zeusz felesége - is beavatkozott, Héraklész 
megszületését késleltetve, Áté, Héra kérésére, hízelkedve lekötötte Zeusz figyelmét. Így a mükénéi királyi trón nem Héraklészre, Zeusz utolsó és legerôsebb félisten fiára, hanem annak unokatestvérére szállt. Zeusz ezért megharagudott - nem a feleségére, Hérára, hanem Átéra; felkapta, és hosszú aranyhajánál fogva megforgatta az istennôt, majd ledobta az Olimposzról a földre - az emberek közé -, ahol azóta van jelen a „bársonytalpú” hízelgés, rábeszélés.

Az Ereboszban lakik Hekaté, az egyik vérbeli alvilági istennô. Édesanyja Asztéria, annak a Létónak a testvére, aki Artemiszt és Apollónt szülte Zeusznak. Hekaté három alakja a mediterrán régió vaskor elôtti anyajogú társadalmának az ôsi istennôjét, annak is a sötét, misztikus változatát idézi: kanca, szuka és oroszlán képében jelenhet meg a búbájosság, a boszorkányság fáklyás istennôje, akinek éjfélkor, keresztutaknál fekete kutyát áldoztak az ókoriak, hogy ezzel a kegyébe férkôzve, védve legyenek a boszorkányok rontásai ellen. Hekaté továbbá a halottak kincseinek ôre, ezért a sírkamrákban oszlopot emeltek a tiszteletére és jelenlétének biztosítására. Az asszonyok szülési fájdalmáért is ó felel - megkönnyítheti vagy megnehezítheti a szülést -, mint a Vajúdás istennője, Prothüraia néven. Szent növénye a fekete nyárfa, szent állata a fekete kutya mellett a menyét. Héraklész születésének már említett késleltetését Héra Hekaté alakját felvéve, mint a Vajúdás istennôje végezte: öregasszonynak álcázva, keresztbe tett lábbal és kézzel leült a ház elé. Amíg ott ült, a saját lánya, a „megsegítô” Eleithüia, a Szülés istennője nem jöhetett a házhoz, ahol Alkméné, Héraklész anyja vajúdott. Látták ezt a házbeliek, sejtették, hogy a Vajúdás istennôje ül ott összefont lábbal, vénasszony képében, de hiába fohászkodtak Zeuszhoz, az nem volt sehol, hiszen éppen Áté hízelkedố csevegését hallgatta. A háziak pedig egy istennôvel nem mertek szembeszállni. Ekkor az egyik szolgáló rászedte Hérát. Kiszaladt a házból, és azt kiáltozta, hogy megszületett Héraklész. A Hekaté szerepét játszó Héra meglepetésében felugrott, feladva a szülést gátló testhelyzetet, mire csakugyan megszületett Héraklész. Héra azonban így is elérte a célját (Héraklészbôl nem lett mükénéi király), de mielôtt távozott, egy pillanat alatt menyétté változtatta a szolgálólányt, akit - mivel az egy, a száján kimondott hazugsággal rászedte - arra ítélt, hogy ô meg ezután a száján keresztül szüljön. Ennek a magyarázata, hogy az ókori görögök, látván a menyétet, ahogy a kicsinyeit viszi, azt gondolták, a menyét a száján keresztül szül. Így vált a menyét Hekaté - a Vajúdás istennőjének - egyik szent állatává.

Az Erebosz lakói továbbá a Bosszúállás és a Lelkiismeret-furdalás kutyatestú, aszszonyfejú, denevérszárnyú istennői (az Erinnüszök, vagy ismertebb latin nevükön a Fúriák), akik Uranosz tengerbe csepegô véréból születtek. Jelképük a korbács, amelylyel a búnöst hajtják szüntelen. Hárman vannak: Alléktó (a Szüntelen), Tisziphoné (a Megtorlás), Megaira (a Harag).

Az éjfürtú Hadész fó jelzôje a „kérlelhetetlen”, hiszen mindenki meghal, így hozzá nem is könyörögtek az emberek, nem emeltek neki templomot, szentélyt sem. Imádkozni is csak szemrehányás formájában, a tehetetlen düh által vezérelve „fohászkodtak” hozzá az emberek, öklükkel a földet döngetve. Hadész kiszemelte magának feleségül egyik nôvérének, Démétérnek, a Gabona istennôjének a lányát, Kórét, a múlandó Lányság istennôjét, akinek maga Zeusz volt az apja. Hadész megkereste Zeuszt a kéréssel, aki be- 
leegyezését adta bátyjának, de mivel mindketten sejtették, hogy nôvérük nem engedné szeretett lányát az alvilágba távozni, abban maradtak, hogy a házasság leányrablásként, titokban történjen. Démétér szeme világa, Kóré a társnóivel Nüsza mellett éppen virágot szedett egy réten, amikor megnyílt a föld, és éjfekete lovak vontatta szekéren az alvilág uralkodója dübörgött a felszínre. Felnyalábolta Kórét, és eltúnt vele. Az alvilági palotában étellel-itallal kínálta Kórét, akit ettől kezdve az alvilág úrnőjének, Perszephonénak (pusztulást hozónak) neveztek. A lány tudta a szokást: az ókorban a házasság akkor válik „törvényessé”, amikor az asszony elôször fogad el ételt a férje kezéból. Innen származik az európai szokás, miszerint egy nô egy férfitól édességet, virágot és parfümöt elfogadhat, anélkül hogy kimutatná hajlandóságát a férfi iránt. Viszont ha ételt - vacsora- vagy ebédmeghívást - elfogad, ezzel kifejezi, hogy hajlandó akár házastársként is elfogadni az udvarlót. Ezért tehát Perszephoné nem evett semmit Hadész házában.

Démétér hosszú keresésre indult a lánya után, és végül Hekaté tanácsára Héliosz napisten árulta el neki, hová túnt Kóré. Démétér azzal állt bosszút Zeuszon, hogy nem tette a dolgát, nem adott gabonatermést az embereknek, így el-elmaradtak a Zeusznak szánt áldozatok is. Végül Zeusz beleegyezett, hogy Démétér kössön egyezséget Hadésszel, hogy csak az év egy bizonyos szakát kelljen Perszephonénak az alvilágban töltenie - ez lett, stílusosan, a tél, amikor a gabonaszóró Démétér istennó bánkódik a lánya után. Mikor Démétér leszállt az alvilágba Hadész házához, elsó kérdése az volt: ettél-e valamit, lányom, Hadész házában? Nem, felelte a lány, de Aszkalaphosz, Hadész kertésze közbeszólt: ô bizony látta, hogy Perszephoné elfogadott egy gránátalmamagot Hadész kezéból, s ezzel „hivatalosan” is az asszonya lett. Azóta a vörös bélú gránátalma - mint piros belsejú, azaz a halállal rokon növény - Perszephoné szent növénye. Démétér mint hatalmas erejú istennő - a görög mitológia istenei eredeti alakjukban két és fél méter magasak voltak - egy hatalmas sziklát gördített Aszkalaphoszra, a rossz hír mondójára, majd Hermész, a lélekkísérô isten segítségével magával vitte a lányát a felszínre - igaz, csak ôszig.

\section{POKOLJÁRÁSOK}

Az alvilág látogatói híres mitológiai alakok. Az alvilágba a lejutás - az élók számára - nem a fơbejáraton, a távoli nyugaton, az Ókeánosz partján lévô feketenyárfa-ligetben történt; ott csak a holtak szellemei gyülekeztek. Az élók a föld hasadékaiban, mély barlangokban ereszkedtek alá. Elsôként az athéni hôs, a Minótaurosz legyőzője, Poszeidón fia, Thészeusz kísértette meg a sorsot az alvilági utazással. Barátja, Peirithoosz azt vette a fejébe, hogy megkéri Perszephoné kezét magától Hadésztól. Thészeusz bátran elkísérte ôt a lehetetlen vállalkozásra. Hadész udvariasan meghallgatta a kérést, majd hellyel kínálta óket a sötét palotája eloótti hatalmas, kôbôl faragott széken, ahonnan - kôvé válva - többé képtelenek voltak felállni. Ezt követôen Héraklész, a valaha élt legnagyobb mitológiai hôs érkezett az alvilágba, híres tizenkét munkája során az utolsó az a - szintén lehetetlen - kívánság volt, hogy hozza fel a rettenetes Kerberosz kutyát. Héraklész azonban nem ismert lehetetlent, és leszállt az alvilágba. Az aszphodéloszi mezókön bandukolt az Erebosz felé, lépteitôl messze rengett a hamumező, s a holtak szellemei szerteszét szaladtak 
ijedtükben. Egyedül két alak várta be félelem nélkül: egyikük a Medúza volt, a kígyóhajú gorgó, akit Perszeusz, a Pusztító ölt meg Athéné istennó segítségével. A másik egy görög hôsnek, a kaledóniai vadászat megrendezójének, Meleagrosznak a szellemalakja volt, Héraklész egykori fegyvertársa. Meleagrosz kérte Héraklészt, hogy húgára, Déianeirára vigyázzon, vegye feleségül. Héraklész meg is ígérte, teljesítette is a kérést, s majdan ennek a lánynak, az utolsó feleségének a féltékenysége okozta a vesztét. ${ }^{4}$

Az alvilágban Héraklész elôször Hadész palotájához ment, hogy engedélyt kérjen nagybátyjától a kutya elhozására. Ez meg is történt, s visszafelé megpillantotta Thészeuszt és Peirithooszt a kôszékben ülve. Thészeuszt, Poszeidón fiát egy hatalmas rántással ki is szabadította, de Peirithooszt nem sikerült, ót ott kellett hagynia. Aszkalaphoszról is lehengerítette a sziklát, de a kertész Démétér istennó átka alatt azon nyomban éjjeli bagollyá változva repült fel a felsố világra. Azóta is a bagoly halálmadár, a huhogás pedig a rossz hír mondását jelenti az európai kultúrákban. ${ }^{5}$ Héraklész felvonszolta Kerberoszt a földre, ahol a napsugártól megijedt, csaholó pokolkutya szétfreccsenó nyálából keletkezett a mérgezô sisakvirág nevú növény.

Egy másik alkalommal Héraklész utazása során meglátogatta egyik barátját, Admétosz thesszáliai királyt, véletlenül éppen akkor, amikor annak felesége, Alkésztisz meghalt. Elôzóleg ugyanis Admétosz megtudta szükségszerú halálának pontos időpontját Apollón istentôl, azzal a kitétellel, hogy megválthatja azt, ha valaki más hajlandó meghalni helyette. Admétosz sorra kereste fel, már évekkel a halála időpontja előtt, a legszegényebb koldusokat és legbetegebb embereket, kincseket és jó életet kínálva nekik a fatális dátumig, ha hajlandók meghalni helyette. Erre senki nem vállalkozott, még a legnyomorultabb ember is görcsösen ragaszkodott az életéhez. Még a király szüleinek - beteg és idôs embereknek - sem akarózott megváltani fiúk életét a magukéval. Egyedül szeretô feleségének, Alkésztisznek nem szólt Admétosz errôl a lehetôségrôl, a nố azonban véletlenül megtudta, és Admétosz tudta nélkül felkínálta a lelkét Thanatosznak, a Halál istenének, aki a Hadészból jött fel a királyért, vagy azért az emberért, aki kész megváltani. Ebben is megmutatkozik a szerelem halálnál is erôsebb ereje. Admétosz kétségbeesett, amikor rájött, mi történt, ráadásul éppen ekkor érkezett a házába a nagybecsú vendég, Héraklész. A rettenthetetlen, féktelen hôst gazdag lakoma várta, s ó nem értette, vendéglátója miért nem mulatozik vele. Amikor megtudta a gyász okát, Alkésztisz alvilágba tartó szelleme után eredt, s a „vasszívú” Halált, Thanatoszt rövid szóváltás után úgy földhöz teremtette, hogy az elengedte Alkésztiszt, akit Héraklész így „a sírból hozott vissza” a férjének.

Amikor maga a Szerelem, Erósz (Ámor) isten is szerelmes lett, kedvesét, Pszükhét (a Lélek megszemélyesítójét) a rossz anyósnak bizonyuló Aphrodité, a szépség istennôje az alvilágba juttatta, mégpedig úgy, hogy egy szelencét bízott rá, amiről a kíváncsi nôként viselkedô Pszükhé úgy tudta, szépségkenốcs lapul benne. Természetesen kinyitotta, de abban mélységes alvilági álom volt, és azonnal végzett vele. Erósz késôbb felhozta kedvesét az alvilágból. Rajta kívül, halála után még egyvalaki menekülhetett ki az alvilágból: Szemelé, Zeusz egyik halandó kedvese, aki addig könyörgött Zeusznak, hogy mutatkozzon meg elótte valódi mivoltában, hogy Zeusz végre engedett, s Szemelé porrá égett az isten jelenlétében. Viszont közös gyermeküket - a legfiatalabb, 
hatalmas olimposzi isten, Dionüszosz (Bacchus), a bor és a mámor istene lett - még meg tudta menteni. Amikor Dionüszosz „felnőtt”, természetesen leszállt az alvilágba, megkereste az anyjának, Szemelének a szellemalakját, és Thüoné néven, a tombolás megszemélyesítőjeként halhatatlanná téve hozta fel magával.

A következô látogató, aki vissza is tért az alvilágból, Orpheusz volt, a thrák csodaénekes, aki dalával mindent el tudott érni. Szerelmét, Eurüdikét vipera marta meg, s meghalt. Orpheusz mély gyászában leszállt az alvilágba, s dalával meglágyította Hadész és Perszephoné szívét; visszaengedték a lányt, azzal a feltétellel, hogy Orpheusz egyszer sem nézhet hátra, vajon Eurüdiké követi-e. Amikor azonban Orpheusz nem tudta megállni, és mégis hátranézett, Eurüdiké szellemalakja végleg visszalebegett az Aszphodéloszba.

Thetiszt, tengeri hableányt, az Elrendezô elv istennôjét egy halandóhoz, Péleuszhoz adták nôül az istenek. Halandó gyermeke, Akhilleusz lett a trójai háború leghíresebb hôse. Thetisz a gyereket születése után levitte az alvilágba, és sarkánál fogva belemártotta a Styx vizébe - így mindenütt sebezhetetlenné vált -, kivéve a sarkát, ahol fogta, s ahol Páris nyila késóbb eltalálta. Innen származik a valaminek a gyenge pontjára utalás: valaminek az „Achilles-sarka”.

A trójai háborúból visszatérve Odüsszeusz tíz éven át bolyongott a Földközi-tenger vidékén, s többek között eljutott - messze nyugaton - az Ókeanoszig, oda, ahol az Akherón folyik a Styx vizébe. Itt, az alvilág határán, az Akherón kapujánál fekete kost áldozva beszélhetett néhány meghalt ismerôse szellemalakjával, akiknek megengedte, hogy igyanak az áldozati bárány vérébôl. Itt tudta meg, hogy a távolléte alatt anyja is, a görög sereg fóvezére, Agamemnón is meghalt, s hogy hogyan juthat haza végre.

Az utolsó ismert alvilági utazó Aeneas volt, Aphrodité istennố halandó fia, aki a trójaiakat segítette a trójai háború idején, s Trója eleste után, a feldúlt városból elmenekülve, Odüsszeuszhoz hasonló kalandos utazást tett a Földközi-tengeren. Itáliában telepedett meg, s ó lett az elsố római királyok ôse. A delphoi jósda jósa, Sibylla kíséri le egy látomásban, s bemutatja neki leszármazottai jövőjét egészen Augustus császár uralkodásáig a Római Birodalomban. Jan Brueghel egész festménysorozaton ábrázolta az alvilági tájat Aeneas alvilági látogatása kapcsán.

\section{HADÉSZ SZEREPE AZ ÓSI EURÓPAI KULTÚRÁBAN}

Az olimposzi istenek általában semmiféle kapcsolatban nem állnak az alvilággal, nemigen merészkedtek le a Hadészba, bár azért akadt néhány kivétel. Dionüszosz például alászállt, hogy visszahozza anyját a halottak közül. Vagy ugyanígy Hermész, akinek egyik feladata, hogy a halottak lelkét kísérje a Hadészba. Démétérnek mint termékenységistennônek is voltak alvilági jellemzôi, hiszen a földbe elültetett magok a halált és a megújulást egyszerre jelképezték (temetés és újjászületés). Azok az istenségek, akik az alvilágban lakoztak, csak ritkán merészkedtek ki onnan. Az égi és az alvilági istenek kultusza a fény és a sötétség, az élôk és a halottak, a föld fölötti és a föld alatti világ ellentéteit tükrözte. Az égi isteneket következésképpen nappal, templomokban, vagy oltárokon bemutatott áldozatokkal tisztelték. Mivel az alvilági istenek a föld alatt 
laknak, a nekik szánt áldozatot éjjel mutatták be, és közvetlenül a földbe juttatták. A tej-, vér- vagy mézáldozatot egy-egy gödörbe öntötték, s ha állatáldozatról volt szó, az alvilági isteneknek szánt állat fekete színú volt.

Az ôsi, kereszténység előtti európai alvilágképben, ahol Hadész az alvilág ura, és a halottak lelke fölött uralkodik, nem ó okozza az emberek halálát, nem viszi el a lelküket, de nem felel meg a kereszténység Sátánjának sem. Hadész nem volt bukott angyal, nem volt gonosz, és nem csábította a halandókat a búnbe, mint a Sátán, más néven Lucifer - Isten egykori kedvenc, de lázadóvá lett arkangyala. Ennek megfelelóen Hadész alvilági birodalma nem felel meg a keresztény vallásban szereplô pokolnak sem. Az ókori görög-római mitológiában tükröződő alvilág egyszerúen a testetlen holt lelkek országa, komor lakhelye. Hadésznak nem voltak kultuszhelyei a régi görög civilizációban. Nem létezett például Hadész-templom, és nem születtek - ókori - szobrai sem. Az egyetlen kivételt képező kultuszhelye Görögországban Élisz mellett volt, a Menta-hegyen, egy elkerített szent terület formájában, ahogy Sztrabón leírja. Hadésztól inkább féltek, mint tisztelték, hiszen már az ókori görögök sem tudták biztosan, mit jelent a halál, van-e halál utáni élet. A nevét sem szívesen ejtették ki, inkább pozitív jelzőket mondtak a neve helyett. Leggyakrabban a föld alatti gazdagságra vagy a föld termőerejére utalva úgy emlegették, hogy „gazdag,” vagyis Plutón. Ezt vették át késóbb a rómaiak, amikor Hadész római megfelelője Pluto lett. Hadésznak az alvilág uraként az volt a feladata, hogy élőket lehetôleg ne engedjen be a birodalmába, s holtakat ne engedjen ki az alvilágból.

Viszont ha nem Hadész a halál okozója, akkor ki? Az ôsi európai vallásban tehát, az ókori görögöknél egyetlen mitológiai alak sem feleltethetô meg a zsidó-keresztény „halál angyalának”. A halálnak volt ugyan önálló istene Thanatosz személyében, de ezt a megszemélyesített halált ritkán említi, ábrázolja az ókori görög múvészet. Amikor szóba kerül, akkor általában ikertestvérével, Hüpnosszal, az Álommal együtt említik. A halál nem félelmetes, sokkal inkább gyors és szelíd, mint az álom. Thanatosz általában nem öli meg az embereket, nem viszi el a lelküket sem. A régi európai kultúra szerint a lélek, a psziché egy kis szárnyas, fecskeszerú lény, amely a halál pillanatában elszáll, s csak lent a Hadészban, az aszphodéloszi hamumezôkön ölt ismét az emberre emlékeztetô testet. Hogy a halál pillanata mikor következik be - öregség, betegség, baleset vagy az ókorban leginkább gyilkosság formájában -, azt a Sors istennók, a Moirák döntik el. Az ô akaratukat Hadész, az alvilág ura sem tudja befolyásolni, de még maga Zeusz, a főisten sem. Nem egy halandó fiát, például Szárpedónt vagy Héraklészt Zeusz akarata ellenére veszítette el.

A három Moira istennô a Földközi-tenger vidékén a késô kôkorszaktól a bronzkoron át a vaskorig évezredeken át uralkodó anyajogú társadalom, a matriarchátus túlélését jelenti az ókori görög vallásban. Nyx az Éjszaka egyik lánya, Ananké a Szükségszerúség alvilági istennője. Neki saját apjától, Erebosztól, az örök sötétségtôl született három lánya, a három Sors istennô, a Moirák, vagy a rómaiaknál a Párkák. Az elsố Klothó; ố a Fonó, aki az emberek sorsát fonja - jelesül lenból, ami egyben a sorsistennôk szent növénye. A második Lakheszisz, a sorsot az embereknek Kiosztó, ó osztja ki születésük pillanatában az emberek sorsát meghatározó lenfonalat. A harmadik sorsistennố Atroposz, az Elháríthatatlan; ô határozza meg, kinek milyen hosszú 
az élete fonala - ahogy sok európai kultúrában ma is így nevezik az élet hosszát. Jelképük a könyörületet szintén nem ismerô, nehéz kôből vagy fémból készített mozsártörô. A sorsistennốk - földrajzilag - a Hadész legsötétebb tartományában, apjuk szúkebb pátriájában, az Ereboszban élnek, mindentôl távol, senki által nem befolyásolva, szenvtelenül végzik örök munkájukat, az emberi életek fonalának készítését, kiosztását és elvágását -, melynek pillanatában a lélek elszakad az enyészetnek induló testtól. Ezt a lelket csak ritkán kíséri a Styx folyóhoz Thanatosz vagy Hüpnosz. Ez az utolsó utaskísérés az utazás istenének, a „háromszor is nagy” Triszmegisztos Hermésznek a feladata, akit ezért pszichopomposznak, azaz „lélekkísérônek” is neveznek.

\section{JEGYZETEK}

1 Hadész kutyája Kerberosz. Ennek a pokoli kutyának egyik testvére az európai népmesék hétfejú sárkánya prototípusa, a lernai mocsárban élố hidra, akit Héraklész gyốzött le. Másik testvére a thébai szfinx, az asszonyfejú szárnyas oroszlán, aki azért lett öngyilkos, mert Oidipusz, a késôbbi thébai király megfejtette a találós kérdését. Európa legrégebbi találós kérdése így hangzott: Ki az, akinek fiatalon négy lába van, késôbb két lába van, idôsen három lába van, de a leggyorsabb akkor, amikor csak két lába van? Illik kitalálni a megfejtést mindenkinek, hiszen már Oidipusz is kitalálta. Kerberosz apja az ismert kígyóhajú tengeri istennô, a Medúza egyik fia, anyja Ekhidna, a kígyónô.

2 A minószi birodalom maradványa a mai Kréta szigetén a knósszoszi palota romja, amit a szantorini vulkán kitörését követố szökôár pusztíthatott el, s ezt az eseményt azonosítják sokan a Platón által említett Atlantisz pusztulásával. A bikaviadal európai szokása is a minószi kultúrából ered, amikor Minósz király félig bikaformájú fia, a Labirintusban élố Minótaurosz tiszteletére fiatal lányok ugrottak át, a feléjük rohanó bikák szarvát megragadva, egy szaltóval a megvadított állatokon egy arénában - mozaikmaradványok tanúsága szerint.

3 Tantalosz szintén Zeusz egyik halandó, kedvenc fia volt. Az ô fia, Pelopsz alapította az elsô, hatalmas görög királyságot, a trójai birodalmat legyőzoo Mükénét. A mükénéi királyok annak emlékére viseltek elefántcsont páncélt a bal vállukon, mert amikor Tantalosz Pelopszot felszolgálta az istenek lakomáján, azok - átlátva a szörnyúséget - nem nyúltak az ételhez, az egy Démétér kivételével, aki lányát gyászolta, s figyelmetlenül megevett egy lapockát. Ezt, amikor az istenek összerakták Pelopszot, elefántcsonttal kellett pótolni.

4 Ismeretes a magyar irodalomból például Arany János verssora: „Pályám bére égetô, mint Nesszosz vére.” Amikor Héraklész utolsó feleségével, Denaeirával hazafelé tartott, egy folyón keltek át, ahol egy Nesszosz nevú kentaur volt a révész. Elôször a nôt vitte át, de a folyó közepén erôszakoskodni kezdett vele, mire Héraklész nyilával lelôtte. A haldokló Nesszosz - hogy bosszút álljon - arra biztatta a lányt, hogy fogja fel a vérét, s ha egyszer úgy érzi, hogy Héraklész már nem szereti, akkor az ô vérébe mártott inget adja rá. A kentaur ugyanis tudta, hogy Héraklész minden nyílhegye mérgezett, miután az általa megölt hidra vérébe mártotta; s így az áldozatainak a vére is mérgezôvé vált. Így is történt, s amikor Héraklész a hidraméreg okozta csillapíthatatlan, égetô fájdalmat már nem tudta elviselni, önkezével vetett véget életének, egy máglyán elégetve magát.

5 Emlékezetes, hogy Aszkalaphosz, Hadész kertésze, a késôbbi halálmadár, a bagoly mondta el, huhogta el a rossz hírt Démétér istennônek, miszerint a lánya menthetetlenül Hadész felesége lett. Az éjjeli ragadozó, a bagoly egyébként rá is szolgált a halált hozó madár imázsára, amennyiben régen csak akkor égették a mécsest éjjel, ha nagybeteg volt a háznál, s a fény az ablakhoz vonzotta az éjjeli ragadozó madarat, a baglyot. Az ilyenkor bekövetkezố halálesetet aztán a szerencsétlen bagoly számlájára írták.

\section{FELHASZNÁLT IRODALOM}

Robert Graves (1981): A görög mítoszok I-II. Európa Könyvkiadó, Budapest. 